\title{
ラウンジ
}

\section{PL 法の施行と化学工業の対応}

\section{稲 葉 實* \\ The Product Liability Law and the Chemical Industry in Japan}

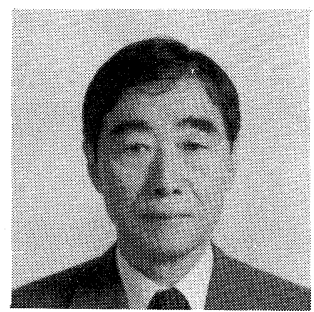

Minoru INABA*

製造物責任法(PL 法)は『製造物の欠陥により人の生 命，身体又は財産に係る被害が生じた場合における製造 業者等の損害賠償の責任について定めることにより, 被 害者の保護を図り，もって国民生活の安定向上と国民経 済の健全な発展に寄与すること (同法第 1 条)』を目的と して, 1994 年 6 月 22 日成立し, 約 1 年にわたる準備期 間を経て 1995 年 7 月 1 日に施行された。

法施行と前後して, テレビ・新聞などでは競って PL 特集が組まれ, 書店の店頭には PL 法の解説書が十数種 類も並べられている。また報道機関や損保会社, 業界団 体等が主催する PL セミナーは, いずれも満員の盛況で ある。けだし PL 法は産業界にとって最大の関心事と いっても過言ではない。

PL 法の制定の経緯, 法律の特徵と内容などの一般的 な情報については, 既に周知のことであるので説明を割 愛し, 本稿では PL という側面からみた化学製品・化学 工業の特徵や，化学工業における対応策の現状に焦点を あてて概観してみたい。

\section{PL からみた化学工業の特徴}

化学工業は次のような観点で, 機械, 電機・電子, 自 動車などの加工・組立型産業とは, 全く異なった側面を 持っている。

(1) 加工・組立と異なり, 化学反応によって生成物が原 材料とは全く異なった性状・性質をもつ場合が多い。

(2) 何工程もの複雑な化学反応を経る例が多く, 化合物
の種類も極めて多い。

(3) 化学物質には人体や環境に対して有害性を示すもの もあり，場合によっては拡大被害につながりやすく， 被害が深刻化する可能性もある(それ故, 各種の法律 に基づいて厳しい規制が行われている)。

(4) 老化・劣化等の経時的な品質変化が発生しやすく, しかもその程度は, 置かれた環境条件によって大きく 左右される。

(5) 化学物質に限定して考えると, 直接一般消費者に販 売されるものは少なく, 多くは次の工程の中間材とし て利用されている。

(6) 特に医薬品のように高度な秘密性を必要とするもの については, 原材料メーカーはその用途さえ知らされ ずに納入するケースを多い。

したがって, 化学工業のメーカーとしては, PL 面で の対応にあたっても，これらの特性をふまえた特段の配 慮が必要となってくる。

\section{2. 化学工業におけるこれまでの PL 訴訟例}

従来, 製造物責任に関する訴訟は, 民法第 709 条以下 (不法行為賠償責任)を根拠に行われた例が多い。米国で はPL 関係の訴訟は，年間 2 万件近くにのぼると言われ るが, 我が国の PL 関連訴訟(昭和 24 年〜平成 6 年 3 月) では, 判決件数でわずか 160 件程度であり，そのなかで 「化学品」によるものは 11 件(ほかに「医薬品」 22 件)にす ぎない(表 1 , 表 2 このほかに裁判上の和解等で解決し

表 1 我が国の製造物責任関係判決件数(製品部門別)

\begin{tabular}{|c|c|c|c|c|c|c|c|c|c|c|}
\hline & 医薬品 & 食品・水 & $\begin{array}{c}\text { 家庭用機 } \\
\text { 械器具 }\end{array}$ & 自動車 & $\begin{array}{c}\text { 産業用機 } \\
\text { 械器具 }\end{array}$ & $\begin{array}{c}\text { ガス・ } \\
\text { 燃炡器具 }\end{array}$ & 化学品 & 不動産 & その他 & 計 \\
\hline $\begin{array}{c}\text { 判決数 } \\
\text { (件) }\end{array}$ & 22 & 19 & 13 & 20 & 20 & 24 & 11 & 24 & 7 & 160 \\
\hline
\end{tabular}

（通産省産業政策局消費経済課編，製造物責任法の解説（通産調査会 1994）より）

* 化成品工業協会

* Japan Dyestuff \& Chemical Industry Association 
表 2 「化学品」の判決例

\begin{tabular}{|c|c|c|c|c|}
\hline $\begin{array}{l}\text { 番 } \\
\text { 号 }\end{array}$ & 製造名 & 裁判所 & 判決日 & $\begin{array}{l}\text { 原告 } \\
\text { から } \\
\text { みた } \\
\text { 結論 } \\
\text { O: } \\
\text { 勝訴 } \\
\times: \\
\text { 敗訴 }\end{array}$ \\
\hline 1 & 洗剤 & 東京地裁 & 42.06 .15 & $x$ \\
\hline 2 & 養鶏飼料 & 福岡地裁久留米支部 & 45.03 .16 & 0 \\
\hline 3 & 肥料 & 高知地裁 & 51.01 .19 & 0 \\
\hline 4 & 高度さらし粉 & $\begin{array}{l}\text { 東京地裁 } \\
\text { 東京高裁 } \\
\text { 最高裁 }\end{array}$ & $\begin{array}{l}61.03 .03 \\
\text { H1.02.06 } \\
\text { H5.03.25 }\end{array}$ & $\begin{array}{l}0 \\
0 \\
\times\end{array}$ \\
\hline 5 & 高度さらし粉 & 東京地裁 & 62.03 .03 & $\bigcirc$ \\
\hline 6 & 外壁材 & 東京地裁 & 62.11 .11 & $\times$ \\
\hline 7 & パーマ液 & 東京地裁 & 63.02 .05 & $x$ \\
\hline 8 & カビとり剤 & 東京地裁 & H 3.03 .28 & 0 \\
\hline 9 & 家畜用飼料 & 岐阜地裁高山支部 & H 4.03.17 & ○ \\
\hline
\end{tabular}

（出典 表 1 に同じ）

たものもあると考えられるが，それらはデータとして 上ってこない)。そして 11 件のうち原告側が勝訴したの は7 件となっている。

このように, 特に化学製品で訴訟事案が少ないのは, 原料や中間体を構成するという化学製品の特性によると ころが多いと推測される。

なお，医薬品の場合は，キノホルム $(9$ 件)，ストレプ トマイシン, クロロキン ( 2 件), 筋肉注射剤( 3 件)など が対象となっており，このほか米ぬか油(4 件・「食品」 に分類されている)などが，広義の化学製品に分類され よう。

このように,これまでのところ化学製品が PL 訴訟に 巻き込まれた例は少なく，ことに中間物としての化学製 品が責任を追及された例はほとんどない。

しかし今後は,

(1) 製造物責任法の施行に伴い, 製品の欠陥を要件とす る欠陥責任に転換されたため, 消費者の立証負担が軽 減されたこと

(2) 消費者サイドの権利意識の向上
等から, 訴訟件数は増加するものと言われており，原料 供給者も訴訟の対象になることが考えられるので，化学 工業としては，これに対する十分な対応策が必要になっ てきている。

\section{3. 製造物責任法における化学工業の位置づけ}

今回施行をみた PL 法は，すべての製造物に適用され るが，そのなかで特に化学工業にとって関わりの深い条 文は, (1)部品・原材料の製造業者の抗弁 (第 4 条 2 項),

(2)除斥期間の特則(第 5 条 2 項)の 2 点であろう。

\section{1. 部品・原材料の製造業者の抗弁}

これは, 製造物(ここでは化学製品)が，他の製造物 (消 費材など)の部品または原材料として使用された場合に, その欠陥がもっぱら「他の製造物」の製造業者が行った設 計に関する指示に従ったことにより生じた場合には，化 学製品の製造業者は免責されるというものである。既に 触れたように，化学品は一般に中間体でその用途は極め て多面的であり，かつ納入に当たっては用途さえ知らさ れないと言ったケースも多い。このため, 化成品工業協 会, 日本化学工業協会は, 中間体に係る責任の限定(原 材料の供給者についての免責条項の設定)を要望した経 緯がある。

本条は，もちろん化学工業のためだけに設けられたも のではなく，下請け中小企業への対応をも配慮して設定 されたものと考えられるが，「材料発注者が行った設計 に関する指示に従った」ものであり，かつ「その欠陥が生 じたことにつき過失がなければ」化学品メーカーは免責 されることとなる。

\section{2. 除斥期間の特則}

除斥期間とは, 時効のひとつで, 損害賠償請求権など, 法律上の権利について定められている存続期間であり， その期間内に権利を行使しないと権利が消滅するもので ある。

一般の不法行為については民法第 724 条後段で, 除斥 期間は「不法行為ノ時ヨリ 20 年」とされているが, PL 法 では，製造物の技術革新が早いことや，製造物の通常使 用期間・耐用年数等も考慮して「製造物を引き渡したと きから 10 年」と短縮された(第 5 条 1 項)。

ところが，化学製品や医薬品では，身体に蓄積するこ とによって人の健康を害する場合や，使用時から一定の 潜伏期間を経てはじめて症状が発現する場合もあり, 10 年の除斥期間では被害者の救済が不可能となることもあ る。

このためPL 法第 5 条 2 項では「(除斥期間は)身体に 蓄積した場合に人の健康を害することとなる物質による 
損害又は一定の潜伏期間が経過した後に症状が現れる損 害については，その損害が生じた時から起算する」とさ れた。

化学工業メーカーとしては, 特にこの点に留意して製 品安全対策に万全を期する必要があろう。

\section{4. 化学工業における PL 対策}

メーカーのPL 対策には, (1) PL 事故の発生を末然に 防止するための予防策(PLP), (2)発生した被害に対応す るための防御策(PLD)があるが，事後処理より予防を行 う方が，はるかに実施が容易で効果も大きい。

PLP の対策にも様々なものがあり，化学工業の各社 ではPLPに重点を置いて, 社内体制の確立, 安全基準 の整備, 製品設計・工程管理・検査体制・文書管理の整 備，さらには従業員の教育など, 多面的な対応策を講じ ている。

たた，各企業の対応策を個別・具体的に論ずることは 不可能であるので, ここでは(社)日本化学工業協会 (以 下「日化協」という)の動きを中心に，化学工業に扔ける PL 対策の動向を観察してみたい。

日化協は, 企業会員 188 社, 団体会員 76 団体で構 成される化学工業の総合的団体であるが, PL 制度につ いては 1991 年同協会の経済委員会のなかに「製造物責任 制度会科会」を設け，立法に際しては各種の意見具申・ 要望を行ってきた。また，下記のように化学業界共通の 各種ガイドラインを作成してきた。

\section{1. これまでに作成されたガイドライン}

ガイドラインとしては, まず「文書作成, 管理と記録 保存」(化学素材メーカーの製造物責任対策における文 書作成, 管理と記録保存),「社内 PL 教育指針」(化学企 業の従業員等に対する製造物責任制度および化学製品安 全対策等に関する教育研修のあり方)が, ともに 1993 年 11 月から 1994 年 3 月にわたって作成された。

また 1994 年 10 月には「企業に打ける紛争処理等に関 するガイドライン」(消費者から製品苦情の申し出が あった場合の処理についての基本的考え方)が検討に入 り，1995 年 3 月には成果が発表されている。

\section{2. 警告表示に関するガイドライン}

化学工業における PL 対策のひとつとして, 製品に係 る警告表示がある。すなわち, 製品の製造者には, ユー ザーに対して, 製品の使用にあたっての危険を適切に警 告する義務があり, 消費者にとってもその適正な使用が 必要となっている。

産業構造審議会答申では, 表示・取扱説明書の充実・ 適正化を通じて製品の安全性や取り扱い上の注意に関す
る情報を消費者に適切に伝達することの重要性を指摘し ている。これを受けて通産省では「表示・取扱説明書適 正化委員会」を設置, 1994 年 10 月には「消費生活用製品 の取扱説明書のあり方について」を，また 1995 年 2 月に は「消費生活用製品の警告表示のあり方について」をとり まとめ, 警告表示の基本的指針として各業界団体等に提 示した(なお通産省では，これと平行して個別製品ごと のケーススタディを行っており，1995 年 5 月にはカラー テレビを，同年 6 月には家庭用洗浄剤・漂白剤を対象に 警告表示のあり方に関するマニュアルを作成している)。

日化協では, 通産省の動きと軌を一にして, 1994 年 5 月表示ワーキンググループを発足させ, さらにその下 部機構として

(1) 説明書等グループ(化学製品の取扱説明書等のあり 方に関するガイドラインの検討)

(2) 容器ラベルグループ(化学製品の容器に表示または 貼付するラベルの表示内容に関するガイドラインの検 討)

(3) マークグループ(化学製品の警告表示のうち, 危険 の種類(状態),行為の禁止等を表すシンボルマーク(絵 表示)についての検討)

を置いて詳細かつ具体的な検討を行った。なおこれら のグループには, 日化協加入の関係団体の専門家も参加 した(ちなみに筆者も「表示 WG」および「マーク G」に参 加した)。

その結果は，通産省の指針の内容をも十分にフォロー したかたちで, 1995 年 3 月, それぞれ「化学製品の取扱 説明書等記載のガイドライン」「化学製品の容器警告表 示のガイドライン」「化学製品の警告表示のためのシン ボルマークに関するガイドライン」として取りまとめら れ，同年 4 月には発表会が行われた。

誌面の都合で，ここにその検討過程や内容を紹介する ことはできないが, 今回定められたシンボルマークの例 を示すと図1のとおりである。

なお,これらのガイドラインは, 化学工業の特性に十 分配虑したとは言っても, 個別品目ごとに起こりうる危 険の種類, 程度, 頻度等は異なるので, これをべースに それぞれの業界団体等で, 製品・製品群ごとにより詳 細・具体的なガイドラインの検討が行われている。

\subsection{MSDS}

直接の PL 対策ではないが, 化学工業で警告表示と関 連して重要な対策に MSDS (Material Safety Data Sheet, 化学物質安全性データシート)がある。

MSDS は，化学物質の安全性に関する特性や取り扱い 上の注意等の安全性情報を記入したシートであり, 事業 


\begin{tabular}{|l|l|l|}
\hline & 毒 \\
\hline
\end{tabular}

注）1「ISO」は ISO-3864「EN 規格」は EC 指令に基づく EN 規格 である

2 「日化協」は，マーク G が新たに提案したもの

3 このほかに, いくつかのマークがあるが省略

化学産業における PL 対策ガイドライン('95.3. 日化協)に よる

図 1 シンボルマークの例

者間で危険有害性を有する化学物質の取り引きを行う際 に交付することにより，化学物質の安全性に関する情報 を積極的に提供していく制度である。

この制度は 1993 年 3 月に定められた「化学物質の安全 性に係る情報提供に関する指針」(通産省，厚生省の共 同告示)によるもので，日化協や各業界団体によって精 力的に具体策が検討され，約 1 年間の準備期間を経て 1994 年 4 月から本格的に実施がス夕ートした。

その対象になる化学物質は, 爆発性, 引火性, 禁水性, 酸化性，急性毒性，腐食・刺激性，特定有害性(例えば がん原性，催奇形性，慢性毒性)などの危険有害性を有 するものである。

この制度は行政指導であって法律で義務づけられたも のではないが，化学物質を原料として使用している事業 場はもとより，運送業者，倉庫業者等にも安全性に関す る情報が提供され，労働災害をはじめとした化学物質に よる災害の防止と安全性の確保を図ろうとするものであ る。

このように, MSDS は直接一般消費者に情報提供を行 うものではないが，PL，なかでも警告表示とも表裏一 体をなすものとして，極めて重要と位置づけられる。

\section{5. 裁判外紛争処理体制(化学製品 $\mathrm{PL}$ 相談センター)}

製品安全対策を講ずるにあたっては，製品事故の未然 防止・再発防止と並んで, 迅速確実な被害救済が極めて 重要である。特に PL 事故のなかでも少額被害のケース については，一般に裁判にはなじまないので，相対(あ いたい)交渉が中心となるが，それで解決できないよう な案件に対応するため, 裁判外紛争処理体制 (Alternative Dispute Resolution：ADR)の整備が望まれ ている。

PL 法の国会における法案審議にあたっても，衆参両 院で「裁判外の紛争処理を充実強化すること」という附帯 決議が採決されている。

通産省でも，相対交涉における公平性・透明性，裁判 における時間的・経済的な負担というそれぞれの問題点 を補うとともに, 紛争解決手段の多様化を図る観点から, ADR の整備を重要と位置づけ, 1994 年 10 月, 「製品分 野別裁判外紛争処理体制の整備について」通達を出し, 主要な業界団体に対し，その実施を要請した。

これを受けて, 既に住宅部品, 家電製品, 家具・文具・ 食器などの生活用品, ガス・石油機器, 自動車, 消費生 活用製品 (SG マーク製品)等の分野で ADR の体制が整 備され，活動を開始している。

化学工業でも 1995 年 6 月 1 日 (法施行の 1 力月前) か ら『化学製品 PL 相談センター』が業務を開始した。同セ ンターは, 日化協が企業会員 181 社, 団体会員 62 団体 との間にネットワークを構築し，PL 紛争解決に向けて の相談ないしあっせんや，PL 紛争以外の化学製品に関 する照会，相談等の業務を行うものである。（筆者の所 属する化成品工業協会もネットワークの一員として参加 している。また医薬品，化粧品等の団体は，別途それぞ れ単独に ADR を設置している)

一般にADR は，当事者からの「相談」や，相対交渉を 促進するための「あっせん」，さらに当事者が希望する場 合には両当事者の主張の調整を行い，和解案を提示して 紛争の解決を図る「調停」の機能があり, 前記各分野の ADR には調停機能まで持つものが多い。その際，調停 の行為は弁護士法第 72 条により弁護士資格が必要なの で, 弁護士・学者・当該技術の専門家, 消費者代表等で 「パネル」を構成して行う場合が通例である。

化学製品 PL 相談センターの場合は, ここで扱う化学 製品に中間物が多いこともあり，とりあえず相談・あっ せんを業務とし，調停については今後の動向をみて，必 要性が高ければその機能を付加することにしている。 
同センターは現在のところ法施行後日が浅いことも あって, 当面クレーム等はほとんどなく, 化学製品その ものについての照会や相談が多いとのことである。

なお，迅速確実な被害救済のためには，製品欠陥の存 在, 欠陥と損害との因果関係などについて, 事故内容に 応じた適切な原因究明の実施が重要である。これには公 的原因究明機関 (化学製品の場合は, 例えば(財)化学品 検査協会, (財)高分子素材センターなど)が携わること になるが，通産省では 1995 年 6 月 1 日，通商産業検査 所 (10月 1 日「製品評価技術センター」に改組)を中核と した「原因究明機関ネットワーク」を発足した。これには 現在 83 の原因究明機関が登録されており, 日化協もこ のネットワークへのアクセスポイントになっている。

\section{まとめ}

以上, PL 法の施行に伴う化学工業の新しい動きを概 観した。化学工業では「警告表示に関するガイドライン」, 「化学製品 PL 相談センター」に見られるように, 総力を あげて製品安全対策にきめ細かな対応を図っている。

PLに対する企業の対応は，単なる自社防衛といった 消極的なものではなく，消費者保護をより優先するとと もに, 安全性のさらなる追求をめざした, 積極的対応が 求められている。

現在, 世界の化学工業の規範となりつつある考え方に,
レスポンシブル・ケア(「責任ある配慮」， RC)がある。 レスポンシブル・ケアは「化学物質を製造し, または 取り扱う事業者が, 自己決定, 自己責任の原則に基づき, 化学物質の開発から製造, 流通, 使用, 最終消費を経て 廃棄に至る全サイクルにわたって「環境・安全」を確保す ることを経営方針として公約し, 安全・健康・環境面の 対策を実行し，改善を図っていく自主管理活動」とされ ている。

$\mathrm{RC}$ は 1992 年開催された国連環境開発会議(UNCED) で,「化学物質の総合安全管理」が合意されたのに基づい て, 国際化学工業協会協議会(ICCA)が推進している国 際的な活動である。我が国では，日化協を中心に 1995 年 4 月「日本レスポンシブル・ケア協議会」が設立され, 活動を開始した(現在化学メーカーを中心に 76 社加盟)。

このように，企業の PL 対策特に製品安全対策は，世 界的潮流である $\mathrm{RC}$ 活動の一環としても位置づけられる ことになる。

いずれにしても PL 法の施行によって, 企業にはより 厳しい責任が課せられることとなるので, 企業の総力を あげて製品安全の確保に取り組む必要があり, 技術や研 究に携わる方々にも，PLに関心と理解を深めていただ くことが望まれる。

(平成 7 年 8 月 29 日受理) 